\title{
Intrapleural analgesia after endoscopic thoracic sympathectomy ${ }^{1}$
}

\author{
Analgesia intrapleural após simpatectomia videotoracoscópica
}

\author{
Patrícia Gomes da Silva ${ }^{\mathrm{I}}$, Daniele Cristina Cataneo ${ }^{\mathrm{II}}$, Fernanda Leite ${ }^{\mathrm{III}}$, Erica Nishida Hasimoto ${ }^{\mathrm{IV}}$, Guilherme Antonio Moreira \\ de Barros $^{\mathrm{V}}$ \\ IFellow PhD degree, Postgraduate Program in Anesthesiology, Botucatu School of Medicine, UNESP, Bauru-SP, Brazil. Responsible for manuscript \\ preparation, acquisition and interpretation of data. \\ IIPhD, Associate Professor, Division of Thoracic Surgery, Botucatu School of Medicine, UNESP, Bauru-SP, Brazil. Conception, design, intellectual \\ and scientific content of the study. \\ IIIAnesthetist, Bauru State Hospital, UNESP, Bauru-SP, Brazil. Acquisition and interpretation of data. \\ ${ }^{\mathrm{IV}}$ Fellow Master degree, Postgraduate Program in General Basis of Surgery, Botucatu School of Medicine, UNESP, Bauru-SP, Brazil. Acquisition and \\ interpretation of data. \\ ${ }^{\mathrm{v}} \mathrm{PhD}$, Associate Professor, Department of Anesthesiology, Botucatu School of Medicine, UNESP, Bauru-SP, Brazil. Advisor and critical revision.
}

\begin{abstract}
PURPOSE: To compare analgesia traditionally used for thoracic sympathectomy to intrapleural ropivacaine injection in two different doses.

METHODS: Twenty-four patients were divided into three similar groups, and all of them received intravenous dipyrone. Group A received intravenous tramadol and intrapleural injection of saline solution. Group B received intrapleural injection of $0.33 \%$ ropivacaine, and Group C $0.5 \%$ ropivacaine. The following aspects were analyzed: inspiratory capacity, respiratory rate and pain. Pain was evaluated in the immediate postoperative period by means of the visual analog scale and over a one-week period.

RESULTS: In Groups A and B, reduced inspiratory capacity was observed in the postoperative period. In the first postoperative 12 hours, only $12.5 \%$ of the patients in Groups B and C showed intense pain as compared to $25 \%$ in Group A. In the subsequent week, only one patient in Group A showed mild pain while the remainder reported intense pain. In Group B, half of the patients showed intense pain, and in Group C, only one presented intense pain.
\end{abstract}

CONCLUSION: Intrapleural analgesia with ropivacaine resulted in less pain in the late postoperative period with better analgesic outcomes in higher doses, providing a better ventilatory pattern.

Keywords: Intrapleural Analgesia. Sympathectomy. Thoracoscopy.

\section{RESUMO}

OBJETIVO: Comparar a analgesia tradicionalmente utilizada para simpatectomia videotoracoscópica à injeção intrapleural de ropivacaína em duas doses diferentes. MÉTODOS: Vinte e quatro pacientes foram distribuídos em três grupos semelhantes, e todos eles receberam dipirona endovenosa. O grupo A recebeu tramadol endovenoso e injeção intrapleural de solução salina. O grupo B recebeu injeção intrapleural de ropivacaína a 0,33\%, e Grupo C ropivacaína a 0,5\%. Os aspectos analisados foram: capacidade inspiratória, freqüência respiratória e dor. A dor foi avaliada no período pós-operatório por meio da escala visual analógica e durante o período de uma semana.

RESULTADOS: Nos grupos A e B, a redução da capacidade inspiratória foi observada no período pós-operatório. Nas primeiras 12 horas de pós-operatório, apenas $12,5 \%$ dos pacientes nos grupos B e C apresentaram dor intensa em comparação a $25 \%$ no Grupo A. Na semana seguinte, apenas um paciente do grupo A apresentou dor leve, enquanto o restante relatou dor intensa. No Grupo B, metade dos pacientes apresentou dor intensa, e no Grupo C, apenas um apresentou intensa dor.

CONCLUSÃO: A analgesia intrapleural com ropivacaína resultou em menos dor no pós-operatório tardio com os melhores resultados analgésicos nas doses mais altas, proporcionando um melhor padrão ventilatório.

Descritores: Analgesia Intrapleural. Simpatectomia. Toracoscopia. 


\section{Introduction}

Localized hyperhidrosis is manifested by excessive sweating due to disrupted sympathetic stimulation, and it has received greater attention from both medical professionals and laymen since the advent of thoracic sympathectomy. Its incidence is estimated for $1 \%$ of the general population, with a prevalence of $2.8 \%{ }^{1-4}$; however, it has been more thoroughly discussed only in the past two decades. Endoscopic thoracic sympathectomy is a rapid, safe and effective procedure for localized hyperhidrosis treatment, and it is also very well accepted by physicians and patients. It enables the visualization of the thoracic sympathetic chain, which is divided and submitted to thermal ablation with minimum injury, thus making the procedure easy and quick ${ }^{5}$ Complications are rare ${ }^{1}$, but some patients experience, despite the simplicity and rapidness of the procedure, intense and sometimes persistent postoperative pain ${ }^{6,7}$. Postoperative pain thus becomes the major aggravation of sympathectomy ${ }^{8}$. It hinders breathing and coughing, thus increasing the incidence of pulmonary complications and requiring systemic administration of opioids, which increases the risk for respiratory depression and, at times, the extension of hospitalization.

Once a local anesthetic is injected into the pleural cavity, it makes direct contact with the exposed tissue, thus enabling long-lasting analgesia without risk for pneumothorax or intravascular anesthetic injection". This technique, which is referred to as intrapleural block, was firstly published in $1986^{10,11}$ using bupivacaine as a local anesthetic for surgeries on the upper abdominal surgeries ${ }^{12}$, and it has also been recently used in thoracic sympathectomy ${ }^{9,13}$. However, central nervous system toxicity was observed when bupivacaine was used in patients with pleural inflammation due to recent pneumonia, thus showing greater anesthetic absorption by injured tissue ${ }^{14}$. In addition to neurotoxicity, the cardiotoxicity of bupivacaine has raised interest in the development of a less toxic local anesthetic with prolonged action. The result was the formulation of ropivacaine, whose absorption is slower, resulting in lower blood levels ${ }^{15}$. Ropivacaine is more lipophilic and, therefore, less toxic than other more potent local anesthetics, such as bupivacaine and levobupivacaine ${ }^{16}$. It is also less neurotoxic than bupivacaine ${ }^{17}$, and propensity to convulsion after levobupivacaine and ropivacaine administration is 1.5- and 2.5-fold lower, respectively, as compared to that of bupivacaine ${ }^{16}$. As regards cardiotoxicity, the plasma concentration of free ropivacaine must be $50 \%$ higher than that of levobupivacaine in order to induce cardiovascular collapse, and successful cardiac resuscitation is more frequent during ropivacaine intoxication ${ }^{17,18}$.
Therefore, ropivacaine represents the safest local anesthetic for performing pleural block.

This study aimed at evaluating ventilatory alterations and the efficacy of immediate and late postoperative analgesia by intrapleural ropivacaine as compared to venous analgesia in endoscopic thoracic sympathectomies.

\section{Methods}

Following approval by the Research Ethics Committee of Sao Paulo State University, 24 male and female patients with indication of sympathectomy for treatment of palmar hyperhidrosis, ASA I and II physical status, without previous pulmonary disease, who had signed a free-consent form and accepted to take part in the protocol, participated in this study. They were all submitted to simple intubation for endoscopic thoracic sympathectomy using the technique of R3/R4 division followed by electrocautery thermal ablation of the third ganglion bilaterally. The patients showing pleural adhesion requiring resection by an electric scalpel were excluded from the protocol due to the fact that they may present stronger pain resulting from manipulation.

The patients were divided into three random doubleblind (surgeon and patient) groups. Group A $(n=8)$ received intravenous dipyrone (30mg. $\left.\mathrm{kg}^{-1}\right)$ and conventional analgesia with intravenous tramadol $\left(1 \mathrm{mg} \cdot \mathrm{kg}^{-1}\right)$ and a bilateral intrapleural injection of placebo: saline solution $(0.9 \%$ - 20ml). Group B $(\mathrm{n}=8)$ received intravenous dipyrone $\left(30 \mathrm{mg} \cdot \mathrm{kg}^{-1}\right)$ and a bilateral intrapleural injection of ropivacaine $(0.33 \%-20 \mathrm{ml})$; and Group C $(n=8)$ received intravenous dipyrone $\left(30 \mathrm{mg}^{-} \mathrm{kg}^{-1}\right)$ and a bilateral intrapleural injection of ropivacaine $(0.5 \%-20 \mathrm{ml})$. The solutions were administered by the surgeon upon sympathectomy completion, one hemithorax at a time, by means of a 12 french nasograstric tube that was manually placed in the intrapleural space through a previous incision and removed after administration as preconized by Stori Jr et al..$^{5}$.

General anesthesia with alfentanil $\left(30 \mu \mathrm{g} \cdot \mathrm{kg}^{-1}\right)$, propofol $\left(2 \mathrm{mg} \cdot \mathrm{kg}^{-1}\right)$ and atracurium $\left(0.5 \mathrm{mg} \cdot \mathrm{kg}^{-1}\right)$ was performed in all patients. Maintenance was made by target-controlled propofol (1 to $\left.3 \mu \mathrm{g} . \mathrm{ml}^{-1}\right)$ and remifentanil $\left(0.1\right.$ to $\left.0.3 \mu \mathrm{g} \cdot \mathrm{kg}^{-1} \cdot \mathrm{min}^{-1}\right)$ infusion. The patients were monitored by electrocardiogram (EQG), pulse oximetry (SpO2), systolic (SAP), diastolic (DAP) and mean arterial pressure (MAP) by a non-invasive method and capnometry (ETCO2). Prior to anesthesia induction and after recovery, respiratory rate (RR) and inspiratory capacity (IC) were evaluated, respectively by visual counting and a portable spirometer.

Pain was assessed by the visual analog scale (VAS; $0=$ 
without pain, $10=$ more severe pain) at 30,60 and 90 min after awake. Postoperative analgesia was evaluated over a one-week period as regards the need for supplementary analgesia orally, and dipyrone (500mg) was used for mild pain, ketoprofen (100mg) for moderate pain and tramadol $(100 \mathrm{mg})$ for intense pain.

The patients were monitored as regards possible mediate postoperative collateral effects, such as breathing difficulty, signs of systemic toxicity, prolonged awake periods and excessive sedation.

The results were expressed as mean \pm standard error of the mean (SEM). Student Newman-Keuls' $t$ test was used for comparison between the groups. They were considered to be significant when $\mathrm{p}<0.05$.

\section{Results}

No statistical difference was observed between the groups as regards age, weight or height (Table 1).

TABLE 1 - Sample features. Age, weight and high (mean \pm standard deviation).

\begin{tabular}{cccc}
\hline & Group A & Group B & Group C \\
\hline$N$ & 8 & 8 & 8 \\
Age (years) & $27.5 \pm 3.3$ & $23.0 \pm 1.8$ & $25.5 \pm 2.1$ \\
$\begin{array}{c}\text { Weight } \\
\text { (kilograms) }\end{array}$ & $65.0 \pm 4.34$ & $60.3 \pm 3.6$ & $69.7 \pm 4.7$ \\
High (meters) & $1.63 \pm 0.03$ & $1.64 \pm 0.02$ & $1.67 \pm 0.04$ \\
\hline
\end{tabular}

Respiratory rates did not show alteration in relation to their control or between the groups (Figure 1).

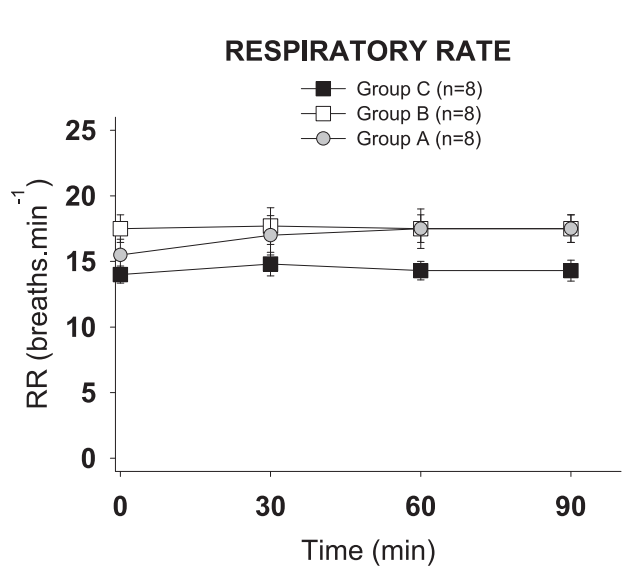

FIGURE 1 - Effect on respiratory rate in groups A, B and C in control, 30,60 and 90 minutes after awakening. The points represent the mean \pm standard deviation. No significant difference between groups.

For Groups A and B, inspiratory capacity in the postoperative period $(0.9 \pm 0.1$ and $0.95 \pm 0.1$ liters $)$ was reduced as compared to that in the preoperative period $(1.76 \pm 0.2$ and $2.0 \pm 0.3$ liters) (Figure 2), but it was not statistically significant in Group C. By using VAS for pain, no differences were observed between Groups $A$ and $C$ in the first 90 min ( $p>0.05$ ), but Group C showed lower pain values.

PAIN SCORE - FIRST 2 HOURS

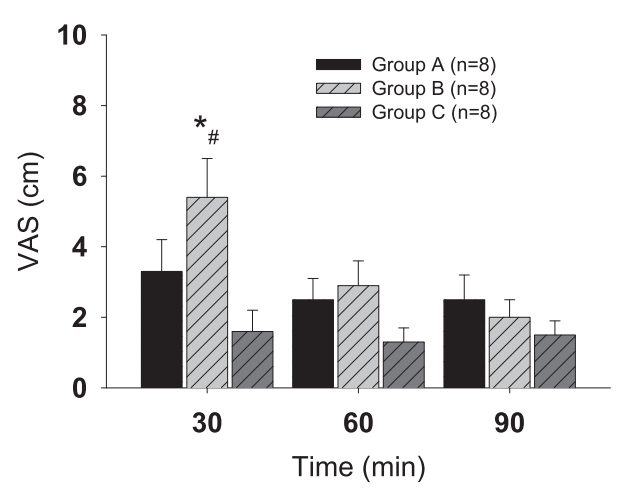

FIGURE 2 - Inspiratory capacity in pre-and postoperatively in groups A, $\mathrm{B}$ and $\mathrm{C}$. The points represent the mean \pm standard deviation. ${ }^{*} \mathrm{P}<0.05$ postoperative versus preoperative.

At $30 \mathrm{~min}$ of the postoperative period, the patients in Group B showed a higher pain level $(5.4 \pm 1.1)$ as compared to the patients in Group A (3.0 \pm 0.8$)$ and C (1.1 10.5$)$ (Figure 3). 
INSPIRATORY CAPACITY

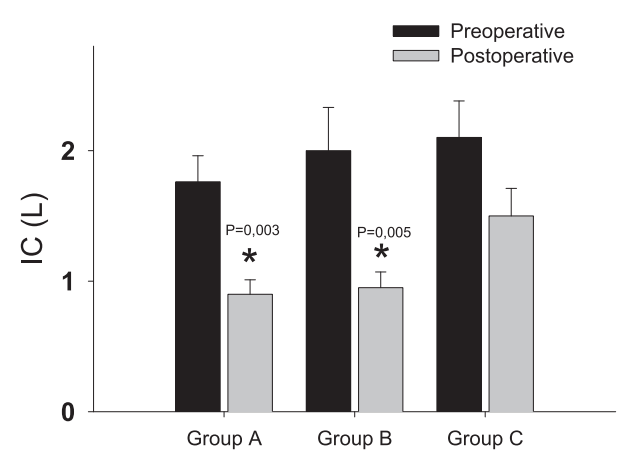

FIGURE 3 - Pain intensity in groups A, B and C, at 30, 60 and 90 minutes postoperatively. The points represent the mean \pm standard deviation. * $\mathrm{P}=0.007$ group $\mathrm{B}$ at $30 \mathrm{~min}$ versus group $\mathrm{A}$ at $30 \mathrm{~min}$ and $\# \mathrm{P}=0.02$ group $\mathrm{B}$ versus group $\mathrm{B}$ for $30 \mathrm{~min}$ to $90 \mathrm{~min}$.

In the first 12 hours after awake, in Group A, 50\% of the patients showed mild pain, $25 \%$ moderate and $25 \%$ intense. In Group B, 25\% showed mild pain, $62.5 \%$ moderate and $12.5 \%$ intense. In Group C, 75\% reported mild pain, 12.5\% moderate and $12.5 \%$ intense (Figure 4). In the late postoperative period, (first week), only one patient in Group A showed mild pain whereas the others reported intense pain and required tramadol. In Group $\mathrm{B}$, half of the patients showed intense pain. In Group C, only one showed intense pain, and the other reported just the use of dipyrone. No patients showed signs or symptoms of systemic intoxication by the local anesthetic or ventilatory difficulties.

\section{PAIN INTENSITY - FIRST 12 HOURS}

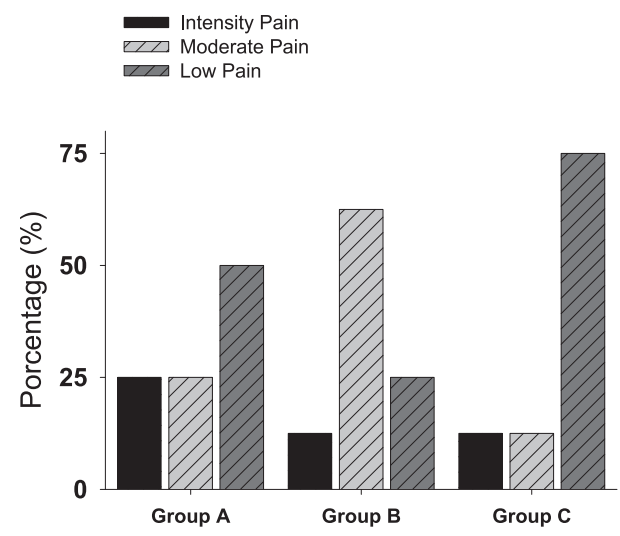

FIGURE 4 - Pain intensity in groups A, B and C, the first 12 hours postoperatively. The points represent the percentage of cases.

\section{Discussion}

Although endoscopic thoracic sympathectomy is a rapid surgical procedure with low morbidity, pain becomes a very important symptom, particularly when it is precipitated by deep aspiration, thus being the major reason for complaint in the postoperative period. For this reason, we opted to study intrapleural analgesia since it is supposedly effective and presents fewer collateral effects, considering the fact that opioids mainly cause nausea, vomiting and sleepiness.

In this study, the intrapleural block by ropivacaine showed improvement in pain levels and reduced consumption of analgesics especially in the late postoperative period as compared to endovenous analgesia. The maintenance of similar inspiratory capacity values to those found for controls showed its benefit expressed by the small alteration in normal ventilatory mechanics.

Intrapleural block has often been used in surgeries such as open cholecystectomy ${ }^{11,19-21}$, showing reduced need for opioids and antiemetics in the postoperative period as well as fast recovery of everyday functions ${ }^{22}$. Its efficacy has also been proven in analgesia for pancreatitis ${ }^{23}$, multiple costal fractures ${ }^{24}$, chronic pain $^{25}$, biopsies and breast surgery ${ }^{26}$.

In thoracic surgery, its indications are questionable, particularly as regards post-thoracotomy pain for lobectomy and pneumonectomy ${ }^{27,28}$. Scheneider et al. ${ }^{29}$ did not show significance in this technique as compared to placebo. On the other hand, it was satisfactory in the post-operative period following thoracotomy for esophagectomy ${ }^{30,31}$, with thoracic pain relief without alteration of abdominal pain.

Some reasons for controversial results include: loss of up to $30 \%$ of the do local analgesic through the thoracic drain, dilution in pleural effusion, bonding to blood proteins, bad distribution in the pleural cavity from where the lung or part of it has been removed. However, the development of minimally invasive approaches combined with thoracoscopy has enabled the effective and safe preservation of the local anesthetic within the thoracic cavity for a long time due to the absence of a drain and pleural effusion.

Assalia et $a l .{ }^{9}$ studied 50 patients submitted to thoracic sympathectomy by using $20 \mathrm{~mL}$ of $0.5 \%$ intrapleural bupivacaine bilaterally with reduction in the pain score and in opioid consumption. A similar result was observed by Lieou et al. ${ }^{13}$ in the first 6 hours after thoracic sympathectomy in 60 patients to whom $10 \mathrm{~mL}$ of $0.5 \%$ intrapleural bupivacaine was administrated bilaterally. In both studies, bupivacaine was compared to saline solution and, in face of the evident intrapleural analgesia in this 
procedure, we opted to compare intrapleural ropivacaine to the venous opioid. It was observed that in the immediate postoperative period, $0.5 \%$ ropivacaine and endovenous tramadol showed the same analgesic effect whereas in the concentration of $0.33 \%$, ropivacaine determined a weaker analgesic effect. However, in the late postoperative period, in both concentrations, ropivacaine determined smaller consumption of analgesics, thus showing that such block is also stronger than conventional analgesia.

The mechanism by which the local anesthetic injected in the intrapleural space produces analgesia has not been fully explained, but it is known that volumes such as $20 \mathrm{~mL}$ can extend subpleurally in up to five adjacent intercostal spaces ${ }^{32}$. Some studies compared volumes of $20 \mathrm{~mL}$ and $40 \mathrm{~mL}$ of bupivacaine and little difference was observed in relation to analgesia duration ${ }^{14,21}$.

As regards concentration, $0.25 \%$ bupivacaine showed to be effective in cholecystectomies when compared to a similar volume in concentrations of $0.375 \%$ and $0.5 \%{ }^{11}$. Badawi ${ }^{33}$ used ketamine and ropivacaine in the concentration of $0.5 \%$ with a dose of $0.3 \mathrm{ml} . \mathrm{kg}^{-1}$, injected into both the pleural and the paravertebral cavities, showing that even in such concentration, paravertebral ropivacaine showed better analgesia than did intrapleural in patients submitted to scoliosis surgery.

Based on those studies, we used $20 \mathrm{~mL}$ of ropivacaine in two different concentrations, and a concentration of $0.5 \%$ ensured satisfactory analgesia in the immediate and late postoperative periods. On the Other hand, a concentration of $0.33 \%$ showed worse analgesia levels in the immediate post-operative period, thus reaffirming the need for larger concentrations.

Most studies show lesser worsening in respiratory function after the intrapleural block ${ }^{12,34}$; others also affirm that the ventilatory parameters cannot be used as predictors for postoperative complications ${ }^{35}$. What is known is that, clinically, the intrapleural block does not determine adverse effects in the respiratory muscle function and, contrarily, it becomes beneficial due to reduced postoperative pain ${ }^{12}$, thus resulting in decreased use of respiration-depressing opioids. Nevertheless, its use in sympathectomy could be worrisome due to its bilateral action on the intercostal nerves and potential block of the phrenic nerve. Previous studies on the bilateral block for sympathectomy did not evaluate ventilatory parameters ${ }^{9,13}$, but in our study, inspiratory capacity maintenance was observed when compared to the preoperative period, even when ropivacaine was used in its largest concentration. These data allows for reaffirming that tramadol worsens the respiratory pattern and contributes to respiratory depression despite the similar pain levels. On the other hand, ropivacaine, even when used bilaterally in a concentration of
$0.5 \%$, does not deteriorate muscle function, which is probably due to the fact that it does not have central action like opioids, thus being a local anesthetic that produces lesser motor block, as well as to the fact that it shows better pain control, allowing for greater thoracic expansibility.

\section{Conclusion}

Intrapleural analgesia by ropivacaine, in relation to conventional analgesia, reduces pain in the late postoperative period of patients submitted to thoracic sympathectomy, and when used in its higher concentration, it determines better global analgesic results and less alteration in ventilatory mechanics, thus producing a better respiratory outcome.

\section{References}

1. Hornberger J, Grimes K, Naumann M, Glaser DA, Lowe NJ, Naver H, Ahn S, Stolman LP, Multi-specialty working group on the recognition, diagnosis, and treatment of primary focal hyperhidrosis. Recognition, diagnosis, and treatment of primary focal hyperhidrosis. J Am Acad Dermatol. 2004;51(2):274-86.

2. Weber A, Heger S, Sinkgraven R, Heckmann M, Elsner P, Rzany B. Psychosocial aspects of patients with focal hyperhidrosis. Marked reduction of social phobia, anxiety and depression and increased quality of life after treatment with botulinum toxin A. Br J Dermatol. 2005;152(2):342-5.

3. Altman RS, Schwartz RA. Emotionally induced hyperhidrosis. Cutis. 2002;69(5):336-8.

4. Lee DY, Hong YJ, Shin HK. Thoracoscopic sympathetic surgery for hyperhidrosis. Yonsei Med J. 1999;40(6):589-95.

5. Stori Jr WS, Coelho MS, Guimarães PSF, Bergonse Neto N, Pizarro LDV. Bloqueio por clipagem de gânglios simpáticos torácicos no tratamento da hiper-hidrose. An Bras Dermatol. 2006;81(5):425-32.

6. Bolotin G, Lazarovici H, Uretzky G, Zlotnick AY, Tamir A, Saute $M$. The efficacy of intraoperative internal intercostal nerve block during video-assisted thoracic surgery on postoperative pain. Ann Thorac Surg. 2000;70(6):1872-5.

7. Furlan AD, Mailis A, Papagapiou M. Are we paying a high price for surgical sympathectomy? A systematic literature review of late complications. J Pain. 2000;1(4):245-57.

8. Lima AG, Marcondes GA, Teixeira AB, Toro IFC, Campos JRM, Jatene FB. The incidence of residual pneumothorax after videoassisted sympathectomy with and without pleural drainage and its effect on postoperative pain. J Bras Pneumol. 2008;34(3):136-42.

9. Assalia A, Kopelman D, Markovits R, Hashmonai M. Intrapleural analgesia following thoracoscopy sympathectomy for palmar hyperhidrosis. Surg Endosc. 2003:17:921-2.

10. Kwalheim L, Reiestad F. Interpleural catheter in the management of postoperative pain. Anesthesiology. 1984;61:A231.

11. Reiestad F, Stromskag KE. Interpleural catheter in the management of postoperative pain: a preliminary report. Reg Anaesth. 1986:11:89-91.

12. Dravid RM, Paul RE. Interpleural block - part 1. Anaesthesia. 2007;62:1039-49.

13. Lieou F J, Lee SC, Ho ST, Wang JJ. Interpleural bupivacaine for relief after transthoracic endoscopic sympathectomy for primary 
hyperhidrosis. Acta Anaesthesiol Sin. 1996;34:21-5.

14. Seltzer JL, Larijani GE, Goldberg ME, Marr AT. Interpleural bupivacaine- a kinetic and dynamic evaluation. Anesthesiology. 1987;67:798-800.

15. Catteral W, MacKie K. Anestésicos locais. In: Goodman \& Gilman. As Bases farmacológicas da terapêutica. 10ed. Rio de Janeiro: McGraw-Hill, 2003. p.285.

16. Feldman HS, Artur RG, Covino BG. Comparative systemic toxicity of convulsant and supraconvulsant doses of intravenous ropivacaine, bupivacaine, and lidocaine in conscious dog. Anesth Analg. 1989:69;794-801.

17. Zink W, Graf BM. The toxicity of local anesthetics: the place of ropivacaine and levobupivacaine. Curr Opin Anaesthesiol. 2008;21:645-50.

18. Nancarrow C, Rutten AJ, Runciman WB, Mather LE, Carapetis RJ, McLean CF, Hipkins SF. Myocardial and cerebral drug concentrations and the mechanisms of death after fatal intravenous doses of lidocaine, bupivacaine, and ropivacaine in the sheep. Anesth Analg. 1989;69:276-83.

19. Strömskag KE, Reiestad F, Holmqvist ELO, Ogenstad S. Intrapleural administration of $0.25 \%, 0,375 \%$, and $0.5 \%$ bupivacaine with epinephrine after cholecystectomy. Anesth Analg. 1988;67:430-4.

20. Laurito CE, Kirz LI, VadeBoncouer TR, Riegler FX, Citron GM, Segil LJ, Pelligrino DA. Continuous infusion of interpleural bupivacaine maintains effective analgesia after cholecystectomy. Anesth Analg. 1991;72:516-21.

21. Strömskag KE, Minor BG, Lindeberg A. Comparison of 40 milliliters of $0,25 \%$ intrapleural bupivacaine with epinephrine with 20 milliliters of $0,5 \%$ intrapleural bupivacaine with epinephrine after cholecystectomy. Anesth Analg. 1991;73:397-400.

22. Dravid RM, Mohroof R, Radhakrishanan L, Al-Hamali S. Interpleural block for day case laparoscopic cholecystectomy. J One-Day Sur. 2006;16(Suppl. 1):A2.

23. Durrani Z, Winnie AP, Ikuta P. Interpleural catheter analgesia for pancreatic pain. Anesth Analg. 1988;67:479-81.

24. Rocco A, Reisetad F, Gudman J, McKay W. Intrapleural administration of local anesthetics for pain relief in patients with multiple rib fractures. A preliminary report. Reg Anaesth. 1986;12:10-4.

25. Finerman SP. Long-term post-thoracotomy cancer pain management with interpleural bupivacaine. Anesth Analg. 1989;68:694-7.

26. Schlesinger TM, Laurito CF, Baughman VL, Carranza CJ. Interpleural bupivacaine for mammography during needle localization and breast biopsy. Anesth Analg. 1989;68:394-5.

27. Rosenberg PH, Sheinin BMA, Lepantalo MJA, Lindfors O. Continuous intrapleural infusion of bupivacaine for analgesia after thoracotomy. Anesthesiology. 1987;67:811-3.

28. Raffin L, Fletcher D, Sperandio M, Mazoit X, Bisson A, Fischer M. Interpleural infusion of lidocaine $2 \%$ with 1:200,000 epinephrine for postthoracotomy analgesia. Anesth Analg. 1994;79:328-34.

29. Sheneider RF, Villamena PC, Harvey J, Surick IW, Beattie EJ. Lack of efficacy of intrapleural bupivacaine for postoperative analgesia following thoracotomy. Chest. 1993;103:414-6.

30. Kambam JR, Hammon J, Parris WC, Lupinetti FM. Intrapleural analgesia for posthoracotomy pain blood levels of bupivacaine following intrapleural injection. Can J Anaesth. 1989;36(2):106-9.

31. Francois T, Blanloeil Y, Pillet F, Moren J, Mazoit X, Geay G, Douet MC. Effects of interpleural administration of bupivacaine or lidocaine on pain and morphine requirement after oesophagectomy with thoracotomy: a randomised, double-blind and controlled study. Anesth Analg. 1995;80:718-23.

32. Reber A, Sheidegger D. An alternative technique for interpleural analgesia. Anesthesiology. 1998;88:553-4.
33. Badawi RB. Interpleural ketamine-ropivacaine mixture compared to thoracic paravertebral block in the management of postoperative pain after thoracoplasty and anterior release of the spine. Eg J Anaesth. 2005;21:247-51.

34. Van Kleef JW, Longerman A, Burm AG, de Voogt JW, Mooren RA, van Kleef-Mannot IM. Continuous interpleural infusion of bupivacaine for postoperative analgesia after surgery with flank incisions: a double-blind comparison of $0.25 \%$ and $0 \mathrm{a} 5 \%$ solutions. Anest Analg. 1992;75:268-74.

35. Pennefather SH, Akrofi ME, Kendal JB, Scawn NDA. Doubleblind comparison of intrapleural saline and $0.25 \%$ bupivacaine for ipsilateral shoulder pain after thoracotomy in patients receiving thoracic epidural analgesia. Br J Anaesth. 2005;94:234-8.

\section{Correspondence:}

Daniele Cristina Cataneo

Departamento de Cirurgia e Ortopedia

Disciplina de Cirurgia Torácica

Faculdade de Medicina de Botucatu - UNESP

18.618-970 Botucatu - SP Brasil

Tel.: (55 14)3811-6091

Fax: (55 14)3815-7615

dcataneo@fmb.unesp.br

Received: April 14, 2011

Review: June 15, 2011

Accepted: July 18, 2011

Conflict of interest: none

Financial source: none

${ }^{1}$ Research performed at Bauru State Hospital, Sao Paulo State University (UNESP), Bauru-SP, Brazil. The article is part of $\mathrm{PhD}$ thesis degree. 